\title{
Research on the development Status of the family services in Jilin province
}

\author{
Dongmei Sun \\ Jilin agricultural university college of humanities, Changchun130118, China \\ Sundongmei-1975@qq.com
}

Keywords: Jilin Province; family services; development Status

\begin{abstract}
Family services as to accelerate the economic growth way, solve the surplus labor force and improve the life quality of people in emerging industries have strong support from state and Jilin province government support. Based on the current situation of domestic service in Jilin Province-depth investigation, around domestic employee's presence service, domestic companies As well as housekeeping demand and other aspects of the investigation, the problems existing in the research the development of industry process, explore the effective ways of Jilin Family Services benign operation and development.
\end{abstract}

\section{The rise and development background of Jilin family service}

\subsection{Domestic service faced with opportunities and mission}

In recent years, Jilin province economic development rapidly, people's living standards continue to improve, consumer attitudes are also changing, Family Services also ushered in the development of the spring. In May 2011, Jilin Bureau officially released the sixth national census bulletin in Jilin Province. Census results show that family size continued to shrink: the census average population per household is 2.94 people, the fifth national census more than 2000 people decreased 3.320 .38 people. Compared with the national average family size is smaller than the national 0.16 people in our province; the province's population aged 65 and over the proportion of the total population is $8.38 \%$. Compared with the 2000 census, the proportion of the population aged 65 and over increased by 2.53 percentage points. Increase in the proportion of aging population rate higher than the national average of 0.62 percent. [1] Small family size, population aging and other practical but also gives the family service mission.

\subsection{Rural surplus labor issues outstanding}

The total amount of Rural Labor Force in Jilin Province is large, rural labor surplus obviously. As China's major agricultural province, at present, the province's total population of about 2680 people, including the rural population number is 1349 million, about $50 \%$ of the province's total population. Currently, our province of rural labor population is 6.69 million, while engaged in labor productivity requires only 200 million people, to remove the transfer of 2.4 million labor force, there are still 2.3 million of surplus labor. [2] These rural surplus labor generally faced cultural level is not high, no other production skills, conservative ideology is lagging behind. How to play to their ability, become our resolve "Three Rural Issues" main task.

\subsection{The advantages of family Services to absorb surplus labor}

Family service around every aspect of people, family life and other basic necessities to start services, people in order to adapt to modern society competition and fast-paced lifestyle, socialization of housework has become increasingly reflect the rigid requirements. In particular the increased economic development, people's income, makes the domestic service in many cities become household consumption needs. With people closely related to the field of household cleaning, confinement nurse, patient nursing care, etc. need to have professional qualities and skills of service personnel to help them accomplish these family labors. These new services can absorb a large number of urban laid-off workers and rural surplus labor. As the state and the Jilin provincial government support for family service, a rapid increase in the number of services the family business, the overall level has improved to some extent, and to further enhance the ability to absorb 
employment, become the main carrier to absorb rural migrant workers and urban unemployed. In 2013, the province's family services to absorb employment were 2.01 million, cumulative 17.31 million, up $12.33 \%$ over the previous year, completed $100.5 \%$ of the plan. Currently, the province's family services business amounted to more than 3,800 households, an increase of $2.7 \%$ over the previous year, the annual turnover of over 1 billion Yuan. (See Table 1.1)

Table 1.1 Jilin province regional domestic service staff units: ten thousand

\begin{tabular}{c|ll|ll|ll|ll|l|l}
\hline Area & $\begin{array}{l}\text { Changchu } \\
\mathrm{n}\end{array}$ & Jilin & $\begin{array}{l}\text { Sipin } \\
\mathrm{g}\end{array}$ & $\begin{array}{l}\text { Liao } \\
\text { yuan }\end{array}$ & Tonghua & $\begin{array}{l}\text { Bai } \\
\text { shan }\end{array}$ & $\begin{array}{l}\text { Bai } \\
\text { chen } \\
\mathrm{g}\end{array}$ & $\begin{array}{l}\text { Song } \\
\text { yuan }\end{array}$ & $\begin{array}{l}\text { Yan } \\
\text { bian }\end{array}$ & Total \\
\hline $\begin{array}{l}\text { In } \\
2012\end{array}$ & 3.22 & 2.93 & 1.05 & 1.03 & 0.89 & 0.82 & 0.87 & 0.56 & 1.13 & 15.41 \\
\hline $\begin{array}{l}\text { In } \\
2013\end{array}$ & 4.11 & 3.73 & 10.9 & 1.07 & 0.93 & 0.86 & 0.91 & 0.59 & 1.16 & 17.31 \\
\hline
\end{tabular}

Data sources: Jilin province club hall (2013)

\section{The basic condition of domestic service in Jilin Province}

Domestic service current major formats is in the form of domestic companies, this article through to the Jilin province 45 domestic companies and domestic service personnel investigation, 300 questionnaires were distributed, 262 questionnaires, recovery was 87\%, efficiency was 82\%. Customer demand for home services status field survey questionnaire 100, 92 parts questionnaires, recovery was 92\%, efficiency was 92\%. Network random sampling Housekeeping willingness questionnaire 61 questionnaires were recovered, at the same time domestic service association Jilin, Changchun domestic service association related to leadership expert interviews.

\section{1the analysis of domestic service workers}

\subsubsection{The cultural level of domestic workers is lower}

Through the investigation of domestic workers, we found that domestic workers with low education level, cultural level is not high. Looked from the education situation in table 2-1, primary education of domestic workers occupies the main body, by cultural level, the skills shortage restrictions, they can not do a good job; can only choose a lower threshold family services. See table 2-1.

Table 2-1 educational situation of domestic workers interviewed

\begin{tabular}{llllc}
\hline education level & $\begin{array}{l}\text { Illiterate or primary } \\
\text { school }\end{array}$ & $\begin{array}{l}\text { Junior } \\
\text { high } \\
\text { school }\end{array}$ & $\begin{array}{l}\text { High school or } \\
\text { college }\end{array}$ & $\begin{array}{l}\text { College degree } \\
\text { or above }\end{array}$ \\
\hline the percentage & $15.6 \%$ & $53 \%$ & $27.7 \%$ & $3.7 \%$ \\
\hline
\end{tabular}

2.1.2 Practitioners type of low-end, highly liquid

Table 2-2 the proportion of domestic workers employed type

\begin{tabular}{cllll|l}
\hline farming type & $\begin{array}{l}\text { household } \\
\text { cleaning } \\
\text { category }\end{array}$ & $\begin{array}{l}\text { tutor } \\
\text { nursery } \\
\text { class }\end{array}$ & $\begin{array}{l}\text { the elderly, sick } \\
\text { care category }\end{array}$ & $\begin{array}{l}\text { money, } \\
\text { Butler class }\end{array}$ & total \\
\hline $\begin{array}{l}\text { service } \\
\text { frequency }\end{array}$ & 192 & 14 & 42 & 8 & 262 \\
\hline percentage & $73.6 \%$ & $5.3 \%$ & $16.1 \%$ & $3 \%$ & $100 \%$ \\
\hline
\end{tabular}

Currently, the family services of Jilin province can be divided into three levels: the primary service based on household cleaning and the elderly patient care, intermediate service was characterized by needs certain knowledge and skills of baby home education classes, advanced services based on the money and family housekeeper, represented. As can be seen from the data in Table 2-2, due to the low overall cultural quality of employees, service type of housekeeping employees are mostly in the low-end home service type. 
Table 2-3 domestic service employed willingness Status

\begin{tabular}{lcclc}
\hline $\begin{array}{l}\text { the proportion } \\
\text { practitioners } \\
\text { wishes }\end{array}$ & less willing & unwilling & $\begin{array}{l}\text { temporarily or not, look at } \\
\text { the situation after }\end{array}$ & willing \\
\hline percentage & $62.4 \%$ & $5.4 \%$ & $10.7 \%$ & $21.5 \%$ \\
\hline
\end{tabular}

Can be seen from Table 2-3 Survey of domestic workers employed in the will, domestic workers had 62.4 percent of choice is not willing to engage in domestic industry, $5.4 \%$ of the domestic workers expressed reluctance to engage in direct domestic industry, but for the life force, there is no way, $10.7 \%$ of people choose temporary or not, the future depends on the situation. Influenced by traditional thinking and so on, they are engaged in domestic work, without a proper understanding of the work leading to strong liquidity.

2.1.3 The domestic workers discrimination phenomenon is serious, low social status

Family service employees low social status, on the one hand from the urban and rural household registration system to limit opposition, "rural people" identity has always been that they can not get the same treatment as city people, on the other hand by its impact in the services "nanny" this title is already contained inferior people despise means. Meanwhile, unable to engage in high-end domestic services, causing the user in the treatment of domestic services and practitioners attitude, inevitably discriminatory vision.

Table 2-4 the present situation of the domestic service personnel discrimination

\begin{tabular}{|c|c|c|c|}
\hline discrimination status & $\begin{array}{ll}\text { often } & \text { discriminated } \\
\text { against } & \end{array}$ & $\begin{array}{l}\text { occasionally } \\
\text { discrimination }\end{array}$ & $\begin{array}{l}\text { never be } \\
\text { discriminated } \\
\text { against }\end{array}$ \\
\hline percentage & $31.2 \%$ & $42.4 \%$ & $26.4 \%$ \\
\hline
\end{tabular}

In Table 2-4, on whether domestic workers suffer discrimination customer survey, we found that $75.4 \%$ of domestic workers have the phenomenon of discrimination in the workplace. Customers and domestic workers are the direct contact of two groups in the labor process, in the process of the domestic workers; the customer's attitude will directly affect domestic workers occupational belonging and sense of identity, which is one of the reasons affect the healthy development of domestic service.

2.1.4 Domestic workers by the low level of protection

At present, domestic service in the early stage of development, many legal norms are very imperfect, the lack of a unified basis in the service agreement, service standards and other aspects, especially the security status of the domestic workers are worrying.

Table 2-5 domestic service personnel pay insurance status

\begin{tabular}{lllll}
\hline $\begin{array}{l}\text { pay } \begin{array}{l}\text { insurance } \\
\text { status }\end{array} \\
\text { percentage }\end{array}$ & $\begin{array}{l}\text { did not pay any } \\
\text { Insurance }\end{array}$ & $\begin{array}{l}\text { pay accident } \\
\text { insurance }\end{array}$ & $\begin{array}{l}\text { pay accident } \\
\text { insurance } \\
\text { pension insurance }\end{array}$ & $\begin{array}{l}\text { pay five insurance } \\
\text { payments }\end{array}$ \\
\hline
\end{tabular}

From table 2-5 housekeeping waiters' personnel proportion pay insurance and pay insurance types as you can see, survey data show that, do not pay any insurance domestic service personnel accounted for 36.8 percent of the total number of domestic, pay only the accident insurance accounted for $47.3 \%$ of domestic workers, only $15.9 \%$ of domestic workers, in addition to enjoy accident insurance, but also enjoy pension insurance. Domestic workers enjoy social security for the narrow, making domestic workers lack a sense of security and identity in work and life.

\subsection{Analysis of domestic service companies}

2.2.1 Development still belongs to the primary stage, most companies is still in the form of the main intermediary system

Judging from the family service agencies, there are two main family services agency labor and 
social security departments to carry out the domestic service and business start-up, domestic enterprises are mainly in the form of employee system, intermediary system and membership. Jilin province domestic service from the 90s of last century began to sprout, at present is still in the primary stage of development, intermediary system is still the main mode of domestic companies. According to the survey, at present, the size of Jilin Province, 57\% of domestic companies are an intermediary system model, but only to serve the local, Jilin province, only a few have a certain financial strength and size of the domestic companies to implement staff system and membership, and start-up chain.

2.2.2 Domestic service enterprises know enough about the government's policy to foster

Table 2-6 is to understand the current national policies for domestic industries

\begin{tabular}{lllll}
\hline $\begin{array}{l}\text { understanding } \\
\text { the situation }\end{array}$ & clear & $\begin{array}{l}\text { some } \\
\text { understanding }\end{array}$ & do not know & total \\
\hline frequency & 3 & 36 & 6 & 45 \\
\hline percentage & $6.7 \%$ & $80 \%$ & $13.3 \%$ & $100 \%$ \\
\hline
\end{tabular}

In the survey, we found that the most troubled enterprise development is the business also wants to develop staff system mode, but many companies do not understand the national policy on family-related services, do not know the state's basic requirements for domestic service, it only leads to the development of enterprises immediate benefits, no long-term development goals. Although the local government and countries each year to foster domestic industry development and promoting industry transformation of each enterprise personnel management system related policies, however, these beneficial business development within the industry policy is not a good implementation into practice, many companies do not make good use of the policy. Also on the other hand, related companies also lack of effective policy interpretation, resulting in blindness of enterprise development.

\subsection{Domestic service market demand analysis}

2.3.1. Housekeeping wishes of customers vary greatly with the actual situation

Table 2-7 Customer will get housekeeping service mode

\begin{tabular}{lllllc}
\hline $\begin{array}{l}\text { housekeepi find a regular } \\
\text { ng way to } \\
\text { get }\end{array}$ & $\begin{array}{l}\text { introduction by find community } \\
\text { the intermediary }\end{array}$ & $\begin{array}{l}\text { introduced by a } \\
\text { friend } \\
\text { acquaintances }\end{array}$ \\
\hline percentage & $83 \%$ & $4.1 \%$ & $4.9 \%$ & $8 \%$ \\
\hline
\end{tabular}

Table 2-8 Customers get housekeeping service way actual situation

\begin{tabular}{|c|c|c|c|}
\hline $\begin{array}{l}\text { housekeepin } \\
\text { g way to get }\end{array}$ & $\begin{array}{l}\text { find a regular } \\
\text { company }\end{array}$ & $\begin{array}{l}\text { introduction by the find community } \\
\text { intermediary }\end{array}$ & $\begin{array}{l}\text { friends } \\
\text { acquaintances }\end{array}$ \\
\hline percentage & $36 \%$ & $21.6 \%$ & $43 \%$ \\
\hline
\end{tabular}

From table $2-7$ to 2-8 investigation we found that, customers choose housekeeping service will, $83 \%$ of customers hope that through formal homemaking company looking for housekeeping waiters. However, in practice the process of hiring domestic workers, mainly from friends and acquaintances presentation (43\%), housekeeping market did not play its due role; customer's needs are not really satisfied. 
2.3.2 The quality of employees, the quality of service remains the customers to choose a major factor in Domestic Service Company

\begin{tabular}{llllc}
\hline $\begin{array}{l}\text { select reason } \\
\text { of domestic } \\
\text { companies }\end{array}$ & $\begin{array}{l}\text { bnterprise } \\
\text { brand }\end{array}$ & service quality & $\begin{array}{l}\text { the quality } \\
\text { employees }\end{array}$ & of service prices \\
\hline percentage & $14.3 \%$ & $48.6 \%$ & $25.4 \%$ & $11.7 \%$
\end{tabular}

We found from table 2- 9, when the customer in the choice of domestic service, the price is not the main factor, quality of service, the quality of employees is still a major factor in customer choice of domestic service companies, followed by the corporate reputation. Seen now, the focus of the market to the domestic service is still the quality and service skills of housekeeping staff.

\section{Family services in the development of Problem Analysis}

\subsection{The influence of traditional ideas}

As the family services is engaged in home affairs related to labor, it is easy to traditional society "nanny" to link with the past, do not get social common recognition. For domestic service personnel, that is, domestic workers are city dwellers or rural people? An ordinary citizen or inferior so-called "servant"? In the survey, over $70 \%$ of them believe that their work inferior, fear of being looked down upon, especially from the original work of laid-off workers feel psychological gap is too big, leading to domestic workers for personal identity and sense of belonging absence career. This is not conducive to the stability of domestic service workers, likely to cause the loss of domestic service workers, also hinder the healthy development of domestic service.

\subsection{Quality of domestic workers should be improved}

For a long time, domestic workers are from rural surplus labor force, laid-off workers play a major role, lack of vocational skills training, domestic workers of varying quality, a lot of domestic workers lower their quality, the original culture to accept less education, it is not a correct view of domestic service industries, awareness training for housekeeping poorly understood. A large part of the personnel is foreign workers, they come from rural areas, less culture, and the lack of urban life experiences, understanding the importance of vocational skills training less, affect the individual's plasticity.

\subsection{Domestic companies intermediary mode hinder the healthy development}

The basic requirements of users for domestic service is safe and reliable and satisfied with the quality, in the survey found that economic income for many families employ domestic workers already have the condition, however, due to the current domestic service market confusion, influenced by some non-standard system of intermediary domestic company, leading the user to find a suitable domestic workers. As the market for domestic companies to set up the threshold is very low, so there are a lot of non-standard phenomena, such as arbitrary charges, service liberalization, there are no objective criteria and guarantee mechanisms, many users can not find domestic workers assured desirable, only to give up hire domestic workers.

\subsection{The legal protection of domestic industries to be healthy}

Currently, the Stakeholders and safeguard mechanism of domestic industry is not perfect, disputes or event processing lack of policy and legal basis, to domestic workers, domestic service companies and customers a lot of worries. Domestic service law is not perfect, housekeeping lack of objective criteria and generally accepted social guarantee mechanisms. Once the client and domestic workers in dispute, it is difficult to find sensible place, causing the psychological burden heavier of customers and domestic workers. At the same time, domestic service companies whether they have legal qualifications, service standards and service agreements is standard, domestic workers rights protection system is perfect, the status quo were to some extent, restricted the healthy and orderly development of domestic service. 


\section{Conclusion}

Through investigation, analysis and research, we propose at the government level, Jilin provincial government should follow the principles of market economy, based on, in accordance with the "market development platform, depending on the regulations as the policy basis, by the government macro-control, self-discipline rely on industry associations," to build market management system of housekeeping services. ${ }^{[3]}$ Such as corporate officer in domestic service, should enjoy employment, insurance, training and other policies in accordance with national and provincial spirit of the document. Through the development of national occupational standards to identify and assess the implementation of the certificate issuance, establish uniform training institutions and training standards, strengthen the guidance of the training, appraisal, and to improve the quality of employees; to strengthen the agency's standard management, to provide the labor contract and service agreement sample, guide sign labor contract, devise ways of social insurance and dispute handling, to strengthen the maintenance of rights and interests protection, in order to enhance domestic stability.

At the enterprise level, implementation of the "employees" management model so that domestic workers have regular professional identity, strengthen brand building and corporate culture, so that domestic workers change their concept of employment, with the occupation of belonging and pride, so loving housekeeping services. Enterprises should be based on the specific circumstances of the service staff carry out the training, grasp the necessary knowledge and skills, improve the quality of family service workers, and to improve quality of service.

\section{Acknowledgments}

The work was financially supported by"Jilin province higher education teaching reform project in 2014","Jilin province education science "twelfth five-year" plan project (GH150200)".

\section{Reference}

[1] Yanfang Zhao. Investigation and Thinking about population issues in Jilin Province [J]. Journal of CHANGCHUN COMMUNIST PARTY.2011 (12)

[2] Xue Zhao, Xiaoshi Xu. Cause of rural surplus labor force in Jilin Province and the resulting status quo [J]. Modern communication. 2013 (03)

[3] Ying Wu. The market size and growth analysis of Changchun domestic service [J]. Economic Geography. 2006 (11). 